\title{
rPCR: A Powerful Tool for Random Amplification of Whole RNA Sequences
}

\author{
Patrick Froussard
}

\author{
Département des Rétrovirus, Institut Pasteur, 75724 Paris Cedex 15, France
}

\section{$\mathbf{T}_{\mathrm{n}}$}

he polymerase chain reaction (PCR), at first used to amplify known DNA sequences present at very low levels in genomic DNA samples, ${ }^{(1-3)}$ was rapidly extended to amplification of RNA sequences by the use of cDNA. ${ }^{(4,5)}$ The PCR method, which requires multiple heat-denaturation steps and was originally established with the Klenow fragment of Escherichia coli DNA polymerase I, now employs thermostable forms of DNA polymerase and two gene-specific primers (GSP) that flank the DNA segment to be amplified. Although PCR is the most widely utilized amplification protocol, known RNA sequences can be amplified alternatively with a RNA transcription-based amplification system (TAS), ${ }^{(6,7)}$ changing the final product from double-stranded DNA to singlestranded RNA. The TAS reaction needs two GSP, with the downstream GSP linked to a RNA polymerase (T7, T3, or SP6) binding site, and is carried out by using sequential cDNA synthesis and RNA transcription, which are displayed as seven steps, including three heat-denaturation steps. Since the original description of the TAS protocol, the reaction conditions have been modified to achieve more productive and quantitative amplification. Thus, the self-sustained sequence replication $(3 \mathrm{SR})^{(8,9)}$ reaction was modeled after the general scheme employed during retroviral replication and does not require heat-denaturation; $10^{8}$ copies of each target molecule can be produced in less than $1 \mathrm{hr}$ with all three enzyme activities from avian myeloblastosis virus reverse transcriptase, Escherichia coli RNase $\mathrm{H}$, and T7 RNA polymerase operating in an efficient and concerted manner.

Other protocols such as rapid amplification of cDNA ends (RACE) ${ }^{(10-12)}$ use only one GSP and permit amplification of a region between a single known short sequence in a cDNA molecule and its unknown $3^{\prime}$ or $5^{\prime}$ end. Also described as one-sided $\mathrm{PCR}^{(13)}$ or anchored PCR, ${ }^{(14)}$ RACE 3 '-end and 5 '-end procedures are performed by using a homopolymeric nucleotide containing an adapter primer that anneals to the cDNA's $3^{\prime}$ or $5^{\prime}$ termini and one GSP. RACE using a randomly primed first-strand cDNA has also been reported recently, ${ }^{(15,16)}$ with the $3^{\prime}$ extension technique assuming the amplification of DNA fragments localized both in large $3^{\prime}$ unsequenced regions and downstream to a $5^{\prime}$ known sequence. Last, an elegant method that employs head-to-tail ligation of specifically primed, single-stranded, firststrand cDNAs with RNA ligase followed by PCR amplification ${ }^{(17)}$ was developed to yield $5^{\prime}$ double-stranded cDNA copies in sufficient abundance for cloning; although there is actually no available data about the efficiency of this technique, it has the potential advantage of circumventing the usual problems associated with the homopolymeric tailing.

\section{PROCEDURES FOR AMPLIFICATION OF WHOLE CDNA POPULATIONS}

\section{Current Strategies}

After developing numerous PCR methods adapted to known DNA fragments or to DNA regions adjacent to sequenced DNA segments, it was tempting for authors to extend these methods to amplification of very low amounts of total cDNA populations to overcome the quantitative limitation of the classical cloning process. This approach would make it feasible to clone genes that are either poorly expressed or transcribed at the level of small cell populations, and that are of great interest for studies in cell differentiation, neurobiology, developmental biology, and related fields. The following approaches, which can be termed sequence-independent PCR (SIPCR) methods because they do not require even one GSP, are presented and discussed below; they generally include a cDNA amplification step prior to construction of the cDNA library.

Specific amplification of total mRNA sequences is facilitated (Fig. 1a) because these sequences come provided with a common poly $(\mathrm{A})^{+}$sequence at their $3^{\prime}$ end that can be used to initiate reverse transcription in vitro by priming with an oligo(dT) polynucleotide associated with an anchor domain (PI-oligo-dT). After tailing of the synthesized, singlestranded $\mathrm{CDNA}$ with $\mathrm{dG}$ or $\mathrm{dC}$ residues, the second strand is usually generated with a primer PII-oligo-dC (or dG), and the subsequent DNA duplex is amplified with both primers PI and PII. ${ }^{(18-21)}$ This current strategy, using four primers, four enzymatic reactions, and two purification steps to eliminate the excess of anchored primers, permits directional cloning and is either comparable to or more efficient than methods employing adapters or linkers for insertion. This is because the sticky ends of both insert and vector are not self-complementary, which prevents the formation of nonproductive dimers; moreover, it allows the establishment of cDNA libraries from a few cells, and possibly a single cell (picogram quantities of mRNA), and in combination with subtractive cloning represents a powerful tool to study gene expression. However, one of the striking features of the amplification of total poly $(\mathrm{A})^{+}$RNA sequences is the observation of a pronounced reaction optimum after which discrete bands of cDNA disappear to give rise to a low-molecularweight "smear." A plausible explanation 
a. Amplification of total mRNRS

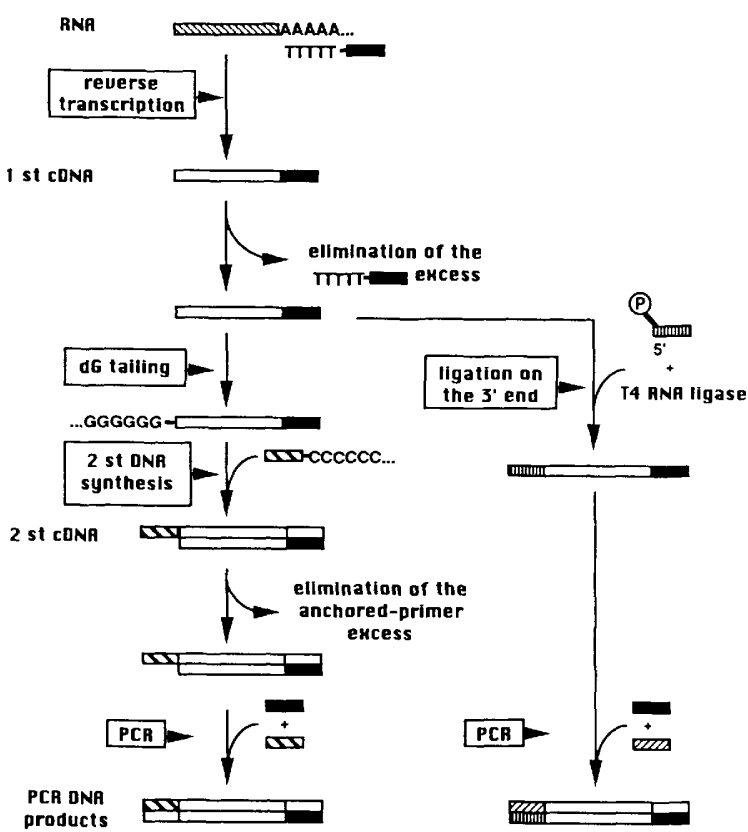

b. Amplification of total cDNAs

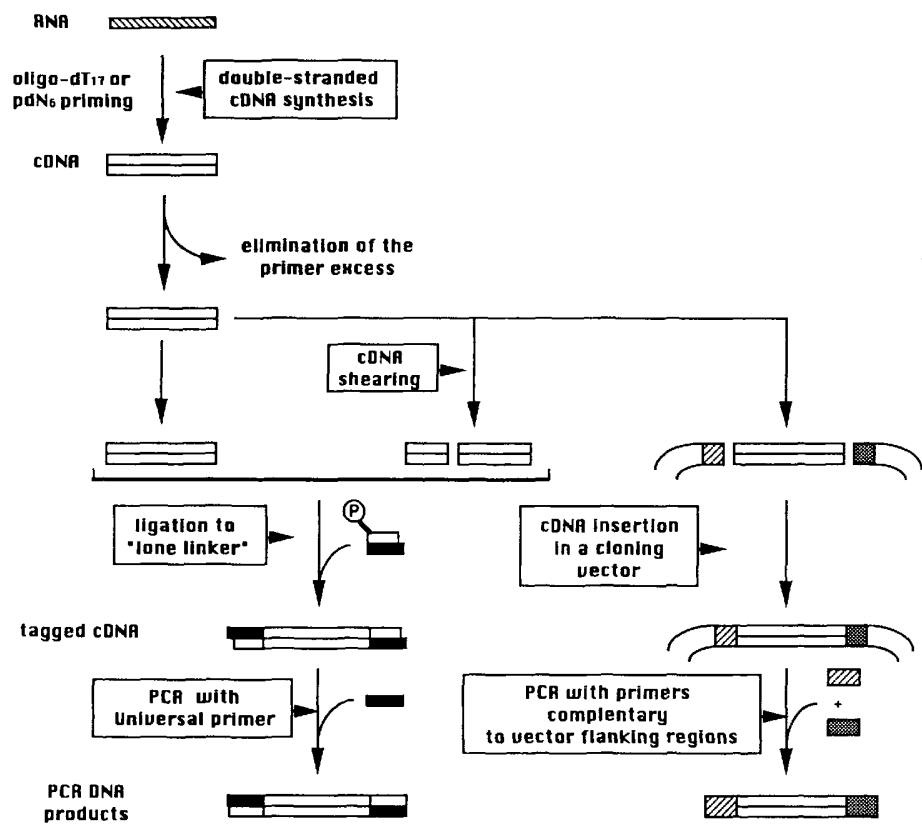

Minimum Amounts of starting

FIGURE 1 Current strategies for amplification of whole cDNA populations. The minimum amounts of starting total RNA indicated in $a$ and $b$ are available when optimistic reaction conditions are used in an attempt to get representative libraries.

is the formation of hybrids between nonhomologous CDNA via their complementary termini, thus inhibiting the copying of large hybrid cDNA species by Taq DNA polymerase. This phenomenon can prevent the isolation of RNA species of low abundance and/or interfere with the relative abundance of primary clones in the library. In addition, dG-tailing has important limitations for further cDNA expression or sequencing. To circumvent these drawbacks, ligation with RNA ligase of an oligonucleotide to the 3 ' end of the first single-stranded cDNA was preferred to the conventional homopolymeric deoxynucleotide tailing. ${ }^{(22,23)}$ Now, when PI is the same as PII, the amplification is performed with only a single universal primer.

Other techniques have been reported where heterogeneous sequences, such as mixtures of blunt-ended genomic DNA fragments or double-stranded cDNAs, are tagged on both ends by universal primers before being amplified through $\mathrm{PCR}^{(24-27)}$ (Fig. 1b). For greatest efficiency, the adapter must have both a nonpalindromic protruding end and a blunt end to prevent the multimerization of linkers; thus, these are called lone-linkers. ${ }^{(28)}$ In addition, the use of a single primer results in a 100 -fold increase in amplification; however, it also results in the loss of the directional cloning opportunity.

PCR has also been useful in approaches toward obtaining equalized $(E L)^{(29)}$ or normalized (NL) ${ }^{(30)}$ cDNA libraries because it permits generation of large double-stranded cDNA quantities prior to proceeding to equalizing steps, which are material consuming. The advantage of EL, as compared to $\mathrm{NL}$, is that PCR can be performed on sheared cDNAs (fragments form 200-400 bp) ligated on both ends to lone linkers rather than on full-length cDNAs; this prevents the preferential amplification of sequences carried by short cDNAs. Furthermore, PCR was demonstrated to be able to drive a very efficient DNA-DNA competitive hybridization prior to selection of subtracted cDNA molecules, ${ }^{31}$ although leading, as in $\mathrm{NL}$, to misrepresentation of large cDNAs because the PCR step was processed on total cDNA populations in the related protocol. However, these last procedures do not seem to be efficient enough when starting from small numbers of cells because both standardization of sonication in EL, or constructions of a classical library before the amplification step as generally reported above, necessitate greater than 200 ng of RNA. Requiring ligation, which is a limiting step in these protocols, involves the use of $>10 \mathrm{ng}$ of starting RNA. Moreover, the disadvantage of most of the SI-PCR methods presented above is that they select small DNA copies preferentially rather than those of $1 \mathrm{~kb}$ or more, giving rise to populations that are not representative of the starting material. Investigators increase the efficiency of cloning long cDNA with a size-selection of the amplified products.

\section{Amplification of Whole CDNA Sequences with Random PCR}

Because random priming is an efficient method for copying DNA or RNA strands and is guaranteed to synthesize shorter than full-length copies of long mRNAs, a 
random priming strategy may be the simplest way of producing representative cDNA libraries by PCR. ${ }^{(32,33)}$ Thus, random PCRs (rPCR; i.e., PCR done with random primers or amplification of DNA fragments randomly synthesized) have been used to amplify whole nucleotidic sequences from 5' to $3^{\prime}$ ends. Primer-extension preamplification (PEP) ${ }^{(34)}$ developed to produce multiple copies of DNA sequences present in a single haploid cell, is carried out for 50 cycles using a mixture of 15-base random oligonucleotides in which any one of the four possible bases can be present at each position; experimental temperature conditions for annealing and extension are $37^{\circ} \mathrm{C}$ and $55^{\circ} \mathrm{C}$, respectively. The original paper shows significant implications for genetic analysis when PCR of a gene specifically follows PEP. Nevertheless, annealing and extension at low temperature and for a large number of cycles result in poor efficiency and may generate mutations and/or recombinations.

rPCR, ${ }^{(35)}$ which is described below for the amplication of whole RNA sequences derived from small amounts of RNA transcripts, is not affected by these inconveniences because of the use of a primer containing a defined $5^{\prime}$ domain attached to a string of random nucleotides; a 21-bp anchored domain allows rPCR to be carried out under stringent conditions. This method permits the amplification of any complex population of DNA fragments of different size and sequence.

\section{Mechanism of the RNA rPCR}

RNA rPCR requires three successive enzymatic reactions: (1) a RNA reverse transcription, (2) a DNA primer extension, and (3) a polymerase chain reaction. As shown in Figure 2, reverse transcription of the RNA target is primed with a 26nucleotide primer containing a random hexamer at its $3^{\prime}$ end (referred to as universal primer- $\mathrm{dN}_{6}$ ) to generate RNADNA hybrid populations. Heat denaturation releases single-stranded cDNA fragments with a universal primer sequence at their 5' end; this step could be advantageously replaced by an extensive RNase $\mathrm{H}$ treatment. This step prevents the possibility of initiating the copying of contaminating DNA fragments because only single-stranded cDNAs, and not double-stranded DNAs, are able to prime in these experimental conditions.

\section{RNA rPCR with Taq DNA polymerase}
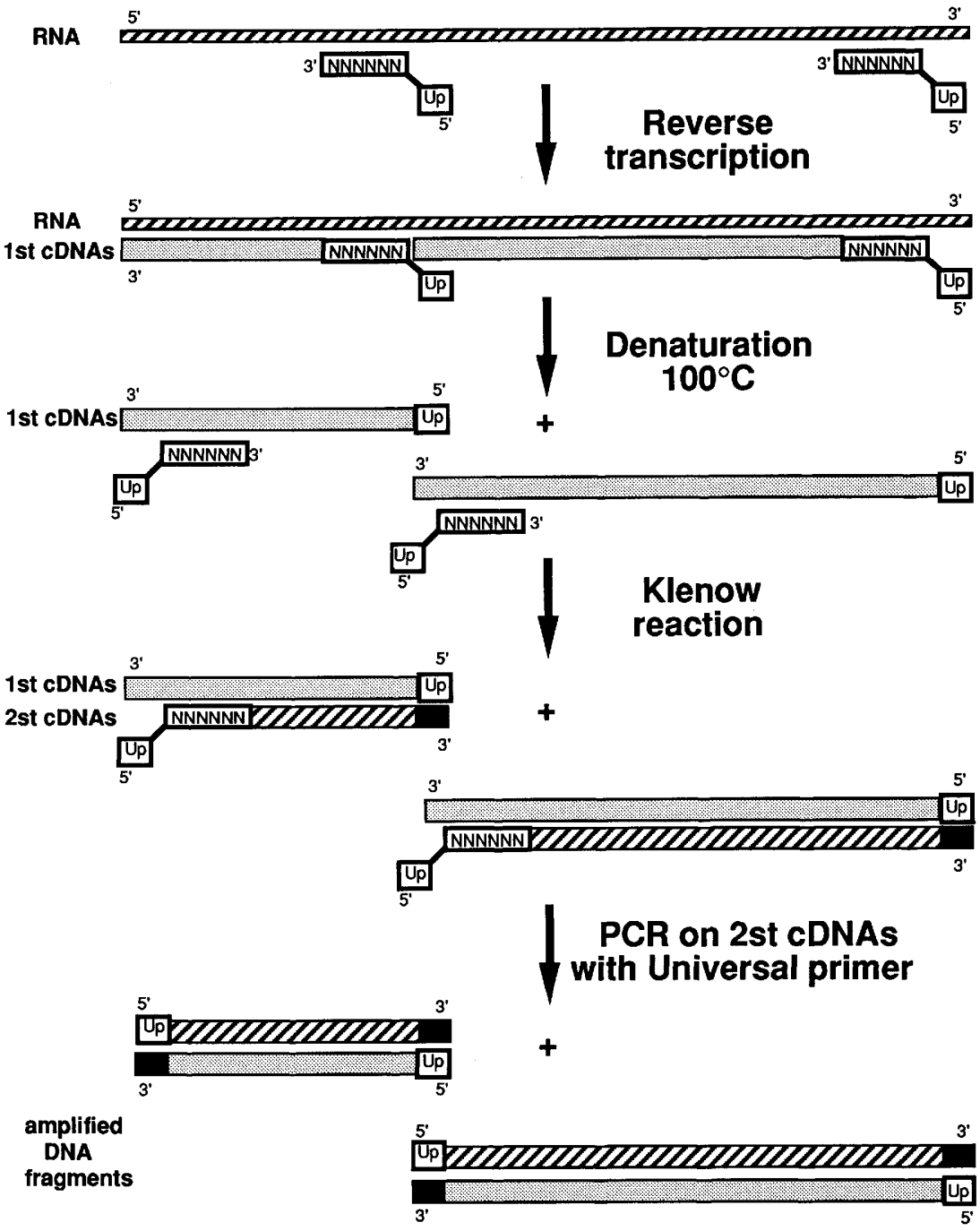

\section{UP [NNNNNN] $3^{\prime}$; Universal primer-dN6 \\ 5 Up $3^{\prime} \quad$; Universal primer}

FIGURE 2 Mechanism of the RNA rPCR.

Using the Klenow fragment of DNA polymerase I, the resulting free cDNAs are, in turn, randomly extended, producing a DNA duplex composed of second-strand cDNAs flanked by the 20 nucleotides of universal primer sequence at their $5^{\prime}$ ends and its complementary sequence at their 3 ' ends. Care has been taken with the universal primer- $\mathrm{dN}_{6}$ concentration because it governs both the size of the synthesized fragments and the efficiency of the reactions. ${ }^{(36)}$ The samples then have to be purified on a spun column to eliminate the excess of universal primer$\mathrm{dN}_{6}$, thus avoiding competition with universal primer for PCR templates. Am- plification of the randomly synthesized second-strand cDNA population is performed in the presence of 20 nucleotides of universal primer and Taq DNA polymerase, essentially as described by Saiki et al. ${ }^{(3)}$

An example of the method is presented in Figure 3 with amplification of a pure 3.6-kb-long MS2 phage RNA. Analysis on agarose gel of the final amplification products shows large amounts of material visible by ethidium bromide staining, with the DNA populations being essentially distributed from 0.4 to $3 \mathrm{~kb}$ and with a maximum number of copies around $0.8 \mathrm{~kb}$; rPCR on total 


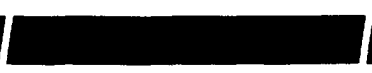

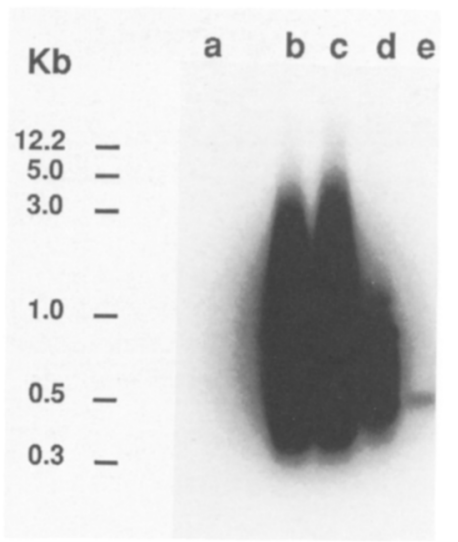

FIGURE 3 Agarose gel electrophoresis analysis of rPCR products encoding MS2 phage sequences. For Southern analysis, a total of 10 $\mu \mathrm{l}$ of the PCR products was electrophoresed in $1.0 \%$ agarose gel, transferred to nitrocellulose, and hybridized with ${ }^{32} \mathrm{P}$-labeled MS2 cDNA probes primed with a random hexamer. Lanes $b-e$ correspond respectively to $10^{-5}, 10^{-6}$, $10^{-7}$, and $10^{-8} \mu \mathrm{g}$ of MS2 starting RNA. (Lane a) A rPCR product obtained with no starting RNA. The relative positions of size markers are shown in $\mathrm{kb}$.

eukaryotic RNA routinely gives DNA fragments around $0.6 \mathrm{~kb}$. In addition, the procedure described above is remarkably efficient because $10^{-6} \mu \mathrm{g}$ of RNA can be amplified; this level seems to correspond to the optimal kinetic conditions because less starting material can generate amplification of one or a few cDNA species that are not representative of the initial RNA sequences (see Fig. 3, lane e). However, rPCR might be improved with a slightly longer sequence of random nucleotides (10-11 nucleotides)..$^{(33,37)}$

\section{Comments on the rPCR Method}

rPCR is a protocol of choice because it makes possible the random amplification of whole cDNA sequences derived from microscale amounts of RNA transcripts (Fig. 4). Preferential selection of a short starting RNA molecule is avoided because $\mathrm{rPCR}$ primes anywhere on the RNA templates, allowing generation of DNA fragments from 0.3 to several kilo bases. Thus, 5' to 3' RNA sequences will be represented in the whole mixed DNA population, in short as well as in long amplified DNA fragments. This quick method allows construction of whole representative cDNA libraries from as lit-

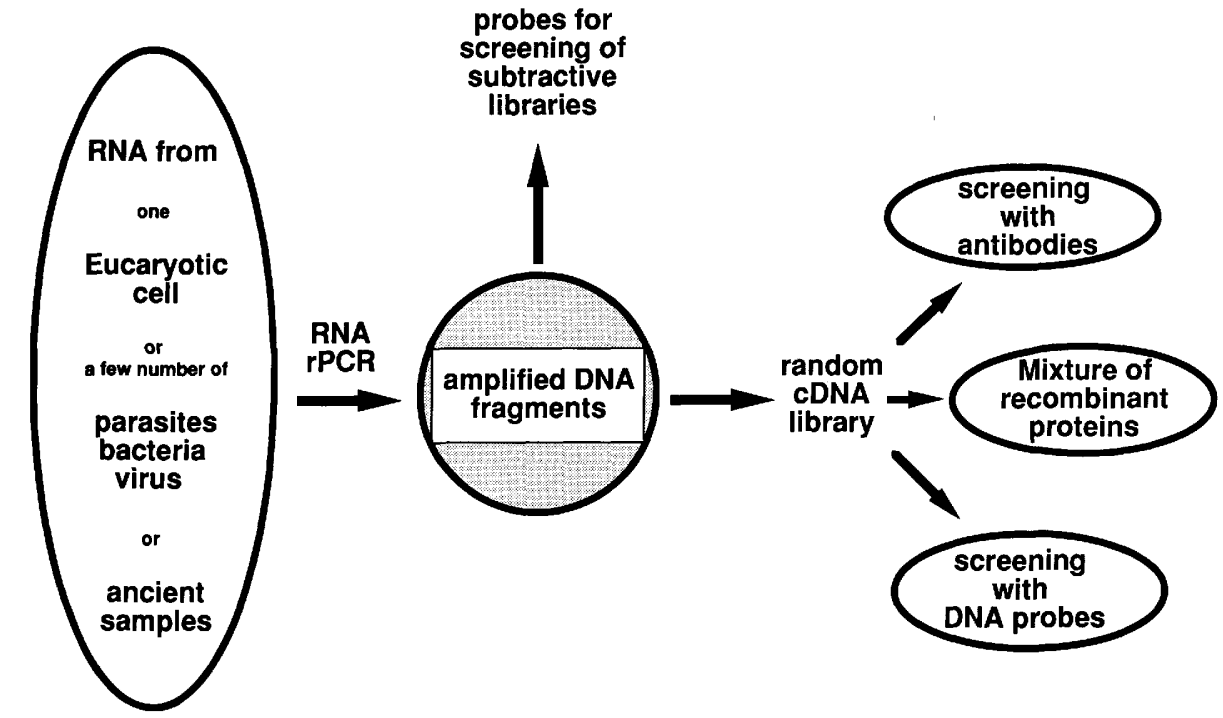

FIGURE 4 Possible strategies with RNA rPCR. tle as one eukaryotic cell, 100 parasites or bacteria, or $10^{5}$ particles of a $9-\mathrm{kb}$ retrovirus, thus lowering the threshold requirements. According to previous data, the error rate should not be more than $0.2-0.3 \%$, a level of fidelity that is quite acceptable for the construction of expression libraries, especially when, as

\section{RPCR PROTOCOL}

1. To an $0.5-\mathrm{ml}$ Eppendorf tube, add: $6 \mu \mathrm{l}$ RNA in distilled water ( $>1$ pg RNA)

2. Heat to $65^{\circ} \mathrm{C}$ for $5 \mathrm{~min}$ and cool rapidly on ice.

3. For reverse transcription, add:

$0.5 \mu$ l RNasin (20 units)

$1.25 \mu \mathrm{l} 10 \times$ reverse transcription buffer $\left(500 \mathrm{~mm}\right.$ Tris- $\mathrm{HCl}, \mathrm{pH} 8.3$ at $43^{\circ} \mathrm{C}, 800 \mathrm{~mm}$ $\mathrm{NaCl}, 80 \mathrm{~mm} \mathrm{MgCl}_{2}, 50 \mathrm{~mm}$ DTT)
$1.25 \mu \mathrm{l}$ dNTP mix (10 mm each)
$1.5 \mu \mathrm{l}$ universal primer- $\mathrm{dN}_{6}(0.1 \mu \mathrm{g} / \mu \mathrm{l}) ; 5^{\prime}$-GCCGGAGCTCTGCAGAAT- TCNNNNNN-3'
$2 \mu \mathrm{l} \quad$ AMV reverse transcriptase (16 units)

4. Incubate for $1 \mathrm{hr}$ at $43^{\circ} \mathrm{C}$, boil the reaction for $2 \mathrm{~min}$, and cool rapidly on ice.

5. For second-strand cDNA synthesis, add:
$24.25 \mu \mathrm{l}$ distilled water
$10 \mu \mathrm{l} \quad 5 \times$ Klenow buffer (kit Multiprime/Amersham)
$1.25 \mu \mathrm{l}$ dCTP $(20 \mathrm{~mm})$
$2 \mu \mathrm{l} \quad$ Klenow fragment (8 units)

6. After $30 \mathrm{~min}$ of incubation at $37^{\circ} \mathrm{C}$, the sample is purified on a Chromo Spin- 400 column (Clontech) to eliminate the excess of universal primer- $\mathrm{dN}_{6}$.

7. $1 \mu \mathrm{l}$ of the randomly synthesized double-stranded cDNA is then amplified essentially as described by Saiki et al. ${ }^{(3)}$ after addition of the following reagents:

$$
\begin{array}{ll}
5 \mu \mathrm{l} & 10 \times \text { PCR buffer (100 mM Tris-HCl, } \mathrm{pH} 8.3,500 \mathrm{~mm} \mathrm{KCl}, 15 \mathrm{~mm} \\
& \mathrm{MgCl}_{2}, 0.1 \% \text { gelatin } \\
2.5 \mu \mathrm{l} & \text { dNTP }(10 \mathrm{~mm} \text { each) } \\
5 \mu \mathrm{l} & \text { universal-primer }(10 \mu \mathrm{M}) ; 5^{\prime} \text {-GCCGGAGCTCTGCAGAATTC-3' } \\
36.5 \mu \mathrm{l} & \text { distilled water }
\end{array}
$$

8. Add 1.5 unit of Taq polymerase (Cetus); the sample is then subjected to 40 cycles of amplification, $94^{\circ} \mathrm{C}$ for $1 \mathrm{~min}, 55^{\circ} \mathrm{C}$ for $1 \mathrm{~min}, 72^{\circ} \mathrm{C}$ for $3 \mathrm{~min}$.

All reagents must be prepared carefully to avoid contamination with traces of RNA or DNA. 
observed with rPCR, the provided cDNA clones are not very long. The libraries are ready then to be screened with specific DNA probes or antibodies. It is also possible to test mixtures of recombinant proteins for their activities in an in vitro or in vivo system. Moreover, cDNAs amplified by rPCR are powerful tools for the screening of subtracted libraries.

Using rPCR, we have cloned and subsequently characterized cDNA fragments that correspond to Mycoplasma transcripts in the supernatant of human leptomeningeal culture cells. ${ }^{(38)}$ These organisms were undetectable in our cell supernatants with the usual enzymatic or immunological tests. Sequence analysis of clones showed that the amplified cDNAs were different except for those exhibiting partially overlapping sequences; the major cDNA populations encoded $16 \mathrm{~S}$ and $23 \mathrm{~S}$ ribosomal RNA. rPCR is used in our laboratory in attempts to identify putative retrovirus sequences poorly represented in human culture cell supernatants.

Other protocols may be preferred for amplification of poly(A) ${ }^{+}$RNA since rPCR involved priming of whole RNA, including nonpolyadenylated RNAs and ribosomal RNA, which represents about $98 \%$ of all cellular RNA; this will result in a 50-fold dilution of the mRNA sequences. Furthermore, annealing of oligo-dT $_{17}$ is more efficient than that of hexarandom primers. However, amplification of total RNA 3 ' ends could be pursued within the framework of our scheme without any significant changes; in this alternative, first-strand cDNA would have to be initiated with a universal primer-oligo-dT before eliminating the primer excess on a poly(A) Sepharose spin column (data not shown). The rPCR reaction then has to be processed as previously described.

rTth DNA polymerase obtained from Perkin-Elmer should simplify RNA rPCR because it associates both reverse transcriptase and DNA polymerase activities. RNA rPCR, using rTth DNA polymerase and our universal- $\mathrm{dN}_{6}$ primers at $37^{\circ} \mathrm{C}$ for annealing and $37^{\circ} \mathrm{C}$ to $70^{\circ} \mathrm{C}$ for extension temperature at steps 1 and 2 , did not work in our hands, probably because of the shortness of the random primer region. This should be tested with a longer random region; thus, 10-15 random nucleotides should ensure both specificity and efficiency of the two first reverse transcription/DNA polymerase reactions.

\section{Extension of rPCR to DNA}

Extension of the rPCR method to genomic DNA was tested in our laboratory by replacing the reverse transcriptase with a Klenow fragment step; analysis of the amplified fragments shows electrophoretic patterns similar to those obtained with RNA rPCR. In addition, amplified samples hybridized with specific DNA probes, demonstrating that rPCR can be used for amplification of total genomic DNA (data not shown).

The efficiency of such an approach was successfully demonstrated recently by PCR amplification of megabase DNA with tagged random primers. ${ }^{(39)}$ As little as $10^{-6} \mu \mathrm{g}$ of DNA molecules and genomes ranging from $400 \mathrm{bp}$ to $40 \mathrm{Mb}$ were readily amplified to amounts that could be seen on ethidium bromide staining gels. The final products were proven to be highly specific, as seen by hybridization to gridded, whole-genome cosmid libraries.

\section{ACKNOWLEDGMENTS}

I wish to thank S. Lefebvre and S. WainHobson for their helpful discussions and comments upon reading the manuscript. I would also like to thank Professor Luc Montagnier for his encouragement in this work as well as for laboratory facilities. This work was supported by grants from the Institut Pasteur and the Centre National de la Recherche Scientifique (CNRS).

\section{REFERENCES}

1. Saiki, R.K., S. Scharf, F.A. Faloona, K.B. Mullis, G.T. Horn, H.A. Erlich, and N. Arnheim. 1985. Enzymatic amplification of $\beta$-globin genomic sequences and restriction site analysis for diagnosis of sickle cell anemia. Science 230: 1350-1354.

2. Saiki, R., T.L. Bugawan, G.T. Horn, K.B. Mullis, and H.A. Erlich. 1986. Analysis of enzymatically amplified $\beta$-globin and HLA-DQ $\alpha$ DNA with allele-specific oligonucleotides probes. Nature 324: 163-166.

3. Saiki, R.K., D.H. Gelfand, S. Stroffel, S.J. Scharf, R. Higuchi, G.T. Horn, K.B. Mullis, and H.A. Erlich. 1988. Primer-directed enzymatic amplification of DNA with a thermostable DNA polymerase. Science 239: 487-491.

4. Rappolee, D.A., D. Mark, M.J. Banda, and Z. Werb. 1988. Wound macrophages expression TGF- $\alpha$ and other growth factors in vivo: Analysis by mRNA phenotyping. Science 241: 708-712.
5. Veres, G., R.A. Gibbs, S.E. Scherer, and C.T. Caskey. 1987. The molecular basis of the sparse fur mouse mutation. Science 237: 415-417.

6. Kwoh, D.Y., G.R. Davis, K.M. Whitfield, H.L. Chappelle, L.J. DiMichele, and T.R. Gingeras. 1989. Transcription-based amplification system and detection of amplified human immunodeficiency virus type 1 with a bead-based sandwich hybridization format. Proc. Natl. Acad. Sci. 86: 1173-1177.

7. Davis, G.R., K. Blumeyer, L.J. DiMichele, K.M. Whitfield, H. Chappelle, N. Riggs, S.S. Ghosh, P. Kao, E. Fahy, D.Y. Kwoh, J.C. Guatelli, S.A. Spector, D.D. Richman, and T.R. Gingeras. 1990. Detection of human immunodeficiency virus type 1 in AIDS patients using amplification-mediated hybridization analyses: Reproducibility and quantitative limitations. J. Infect. Dis. 162: 13-20.

8. Guatelli, J.C., K.M. Whitfield, D.Y. Kwoh, K.J. Barringer, D.D. Richman, and T.R. Gingeras. 1990. Isothermal in vitro amplification of nucleic acids by a multienzyme reaction modeled after viral replication. Proc. Natl. Acad. Sci. 87: 1874-1878.

9. Fahy, E., D.Y. Kwoh, and T.R. Gingeras. 1991. Self-sustained sequence replication (3SR): An isothermal transcription-based amplification system alternative to PCR. PCR Methods Applic. 1: 25-33.

10. Frohman, M.A., M.K. Dush, and G.R. Martin. 1988. Rapid production of full length cDNAs from rare transcripts: Amplification using a single gene specific oligonucleotide primer. Proc. Natl. Acad. Sci. 85: 8998-9002.

11. Frohman, M.A. 1990. RACE: Rapid amplification of cDNA ends. In PCR protocols: $A$ guide to methods and applications (ed. M.A. Innis, D.H. Gelfand, D.H. Sninsky, and T.J. White), pp. 28-38. Academic Press, San Diego.

12. Schuster, D.M., G.W. Buchman, and A. Rashtchian. 1992. A simple and efficient method for amplification of cDNA ends using 5' RACE. Focus 14: 46-52.

13. O'Hara, Q., R.L. Dorit, and W. Gilbert. 1989. One-sided polymerase chain reaction: The amplification of cDNA. Proc. Natl. Acad. Sci. 86: 5673-5677.

14. Loh, E.Y., J.F. Elliot, S. Cwirla, L.L. Lanier, and M.M. Davis. 1989. Polymerase chain reaction with single sided specificity: Analysis of T cell receptor $\delta$ chain. Science 243: $217-220$.

15. Harvey, R.J. and M.G. Darlison. 1991. Random-primed cDNA synthesis facilitates the isolation of multiple $5^{\prime}$-cDNA ends by RACE. Nucleic Acids Res. 19: 4002.

16. Fritz, J.D., M.L. Greaser, and J.A. Wolff. 1991. A novel 3' extension technique using random primers in RNA-PCR. Nucleic Acids Res. 19: 3747.

17. Hofmann, M.A. and D. Brian. 1991. A 
PCR-enhanced method for determining the 5 ' sequence of mRNAs. PCR Methods Applic. 1: 43-45.

18. Belyavsky, A., T. Vinogradova, and K. Rajewsky. 1989. PCR-based cDNA library construction: General cDNA libraries at the level of a few cells. Nucleic Acids Res. 17: 2919-2932.

19. Welsh, J., J.P. Liu, and A. Efstratiadis. 1990. Cloning of PCR-amplified total cDNA: Construction of a mouse oocyte cDNA library. Genet. Anal. Techn. Appl. 7: 5-17.

20. Domec, D., B. Garbary, M. Fournier, and J. Bonnet. 1990. cDNA library construction from small amounts of unfractionated RNA: Association of cDNA synthesis with polymerase chain reaction amplification. Anal. Biochem. 188: 422-426.

21. Hla, T. and T. Maciag. 1990. Isolation of immediate-early differentiation mRNAs by enzymatic amplification of subtracted cDNA from human endothelial cells. Biochem. Biophys. Res. Commun. 167: 637643.

22. Dumas, J.B., M. Edwards, J. Delort, and J. Mallet. 1991. Oligonucleotide ligation to single-stranded cDNAs: A new tool for cloning $5^{\prime}$ ends of mRNAs and for constructing cDNA libraries by in vitro amplification. Nucleic Acids Res. 19: 52275232.

23. Troutt, A.B., M.G.M. Heyzer-Williams, B. Pulendran, and G.J.V. Nossal. 1992. Ligation-anchored PCR: A simple amplification technique with single-sided specificity. Proc. Natl. Acad. Sci. 89: 9823-9825.

24. Pfeifer, G.B., S.D. Steigerwald, P.R. Mueller, B. Wold, and A.D. Riggs. 1989. Genomic sequencing and methylation analysis by ligation mediated PCR. Science 246: 810-813.

25. Akowitz, A. and L. Manuelidis. 1989. A novel cDNA/PCR strategy for efficient cloning of small amounts of undefined RNA. Gene 81: 295-306.

26. Lüdecke, H.J., G. Senger, U. Claussen, and B. Horsthemke. 1989. Cloning defined regions of the human genome by microdissection of banded chromosomes and enzymatic amplification. Nature 338: 348350.

27. Timblin, C., J. Battey, and W.M. Kuel 1990. Application of PCR technology to subtractive cDNA cloning: Identification of genes expressed specifically in murine plasmacytoma cells. Nucleic Acids Res. 18: $1587-1593$.

28. Ko, M.S.H., S.B.H. Ko, N. Takahashi, and K. Abe. 1990. Unbiased amplification of a highly complex mixture of DNA fragments by lone linker-tagged PCR. Nucleic Acids Res. 18: 4293-4294.

29. Ko, M.S.H. 1990. An equalized cDNA library by the reassociation of short double-stranded cDNAs. Nucleic Acids Res. 18: $5705-5711$.
30. Patanjali, S.R. 1991. Construction of a uniform-abundance (normalized) cDNA library. Proc. Natl. Acad. Sci. 88: 19431947.

31. Lebeau, M.C., G. Alvarez-Bolado, W. Whali, and S. Catsicas. 1991. PCR driven DNA-DNA competitive hybridization: A new method for sensitive differential cloning. Nucleic Acids Res. 19: 4778.

32. Kaiser, K. 1990. New directions in cDNA cloning: 1 . Directional cloning methods. Technique 2: 1-17.

33. Kaiser, K. 1990. New directions in cDNA cloning: 2 . Towards a library from a single cell. Technique 2: 51-64.

34. Zhang, L., X. Cui, K. Schmitt, R. Hubert, and W. Navidi. 1992. Whole genome amplification from a single cell: Implications for genetic analysis. Proc. Natl. Acad. Sci. 89: $5847-5851$.

35. Froussard, P. 1992. A random-PCR method (rPCR) to construct whole cDNA library from low amounts of RNA. Nucleic Acids Res. 20: 2900.

36. Hodgson, C.P. and R.Z. Fisk. 1989. Hybridization probe size control: Optimized oligolabelling. Nucleic Acids Res. 15: 6295.

37. Goulian, M., S.H. Goulian, E.E. Codd, and A.Z. Blumenfield. 1973. Properties of oligonucleotides that determine priming activity with Escherichia coli deoxyribonucleic acid polymerase I. Biochemistry 12: 2893-2901.

38. Froussard, P. 1991, unpublished results.

39. Grothues, D., C.R. Cantor, and C.L. Smith. 1992. PCR amplification of megabase DNA with tagged random primers (T-PCR). (in press). 


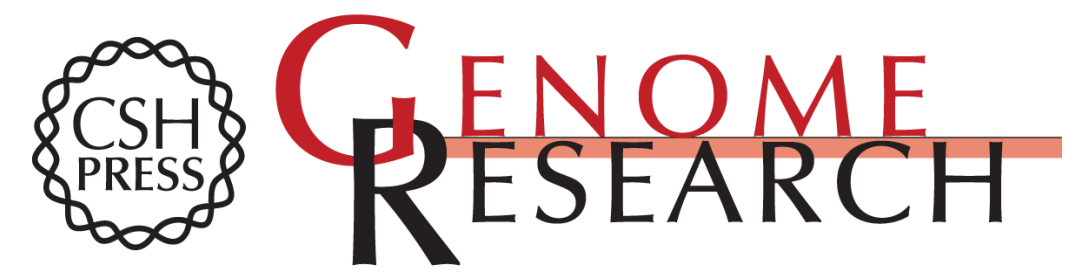

\section{rPCR: a powerful tool for random amplification of whole RNA sequences.}

P Froussard

Genome Res. 1993 2: 185-190

Access the most recent version at doi:10.1101/gr.2.3.185

References This article cites 36 articles, 13 of which can be accessed free at:

http://genome.cshlp.org/content/2/3/185.full.html\#ref-list-1

\section{License}

Email Alerting Receive free email alerts when new articles cite this article - sign up in the box at the Service top right corner of the article or click here.

\section{Affordable, Accurate Sequencing.}

To subscribe to Genome Research go to:

https://genome.cshlp.org/subscriptions 